\title{
Estimation of Nucleic Acids in Microorganisms
}

\author{
(First Report) \\ On the Estimative Observation of Nucleic Acids in \\ Salmonella abortivo-equina \\ By \\ Hisashi Sato \\ (传 藤 誉)
}

(From the Bacteriological Department, Faculty of Medicine, Tohoku University. Director: Prof. M. Kuroya)

(Received for publication, June 11, 1951)

Two ways are known to estimate the nucleic acids as follows:-One is to try directly by means of staining the nucleic acids with specific dyes histochemically, ${ }^{11}$ the other is to determine characteristic constituents of each nucleic acid which are separated from nucleic acids by various methods. The latter consists of two main methods, namely either to estimate ribose and desoxyribose or to estimate phosphor.

The former was reported by Schneider ${ }^{2}$ and not to separate ribonucleic acid (RNA) or desoxyriboucleic acid (DNA) from each other, but to determine spectrophotometrically each of both sugars in mixture by specific colour reactions after the deproteinization with hot trichloroacetic acid.

In the latter the substrate was treated with relatively strong alkali, and under this condition RNA is transformed into acid-soluble compounds, whereas DNA is quantitatively precipitated on acidification of the alkaline hydrolysate. Schmidt and Thannhauser" estimated the amount of each of nucleic acids by the determination of phosphor separated into two fractions mentioned above.

In the method of Schneider, he used orcinol, diphenylamine and carbazole colour reactions. If the extracted samples contain the protein or polysaccharide-compounds, however, they will make difficult this colorimetric estimation of nucleic acids, especially for our unsufficient apparatus and equipments; besides the different resistance of purineand pyrimidine-nucleotides toward hydrolysis presented another difficulty for the same purpose, as it arrested attention of Levene et al., ${ }^{4)}$ and furthermore, as it was stressed also by Chargaff and Vischer, ${ }^{6}{ }^{6}$ Schmid ${ }^{6)}$ and Schneider.

The author estimated the nucleic acids of Salmonella abortivo-equina 
in various growth stages with the combined and somewhat modified method of these two different procedures.

Although the estimation of the nucleic acid amounts of various bacteria has been done already in detail by Boivin, Vendrely, Leonardi ${ }^{7)}$ and Stephenson, ${ }^{8)}$ the author estimated these of Salmonella abortivo-equina in order to prepare for the further studies to estimate the nucleic acids in various bacteria in various conditions.

\section{EXPERIMENTAL}

A strain of Salmonella abortivo-equina was cultivated in broth medium at $37^{\circ} \mathrm{C}$ by shaking during different hours, then formalin was added into it at rate of 0.5 per cent. After several hours the bacteria were washed with cold water in order to remove the broth constituents after Levy.9)

\section{TABLE I}

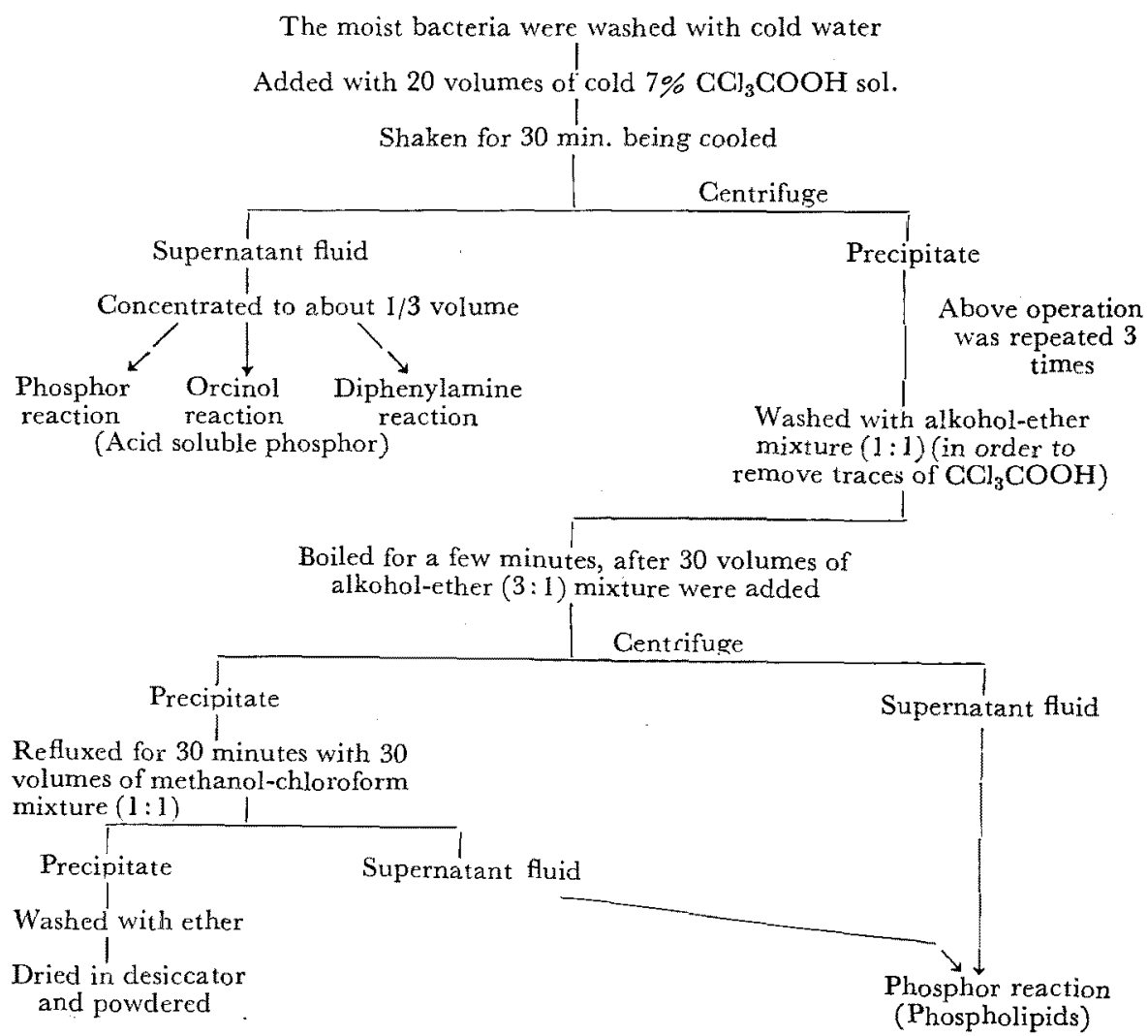

The Table shows the procedure which remove the "acid-soluble phosphor" and "phospholipides." This is done in a low temperature under $5 \mathrm{C}$ at least, which was required for the extraction of "acid-soluble phosphor" from the bacteria, as Levy described. 


\section{TABLE II}

\section{Dried bacteria}

Suspended in $1 \mathcal{N}$. KOH sol. $50 \mathrm{cc}$. per g. of dried bacteria allowed to stand for 19-24 hrs. in $37^{\circ} \mathrm{C}$ until it dissolved completely

Neutralized with $\mathrm{HCl}$ 1

Concentrated to $1 / 2$ volume under reduced pressure (with attention to $\mathrm{pH}$ occasionally)

Alcohol was added at the rate of $40-50 \%$,

Made to $\mathrm{pH}$ 1.2-1.4 with $\mathrm{CCl}_{3} \mathrm{COOH}$ sol.

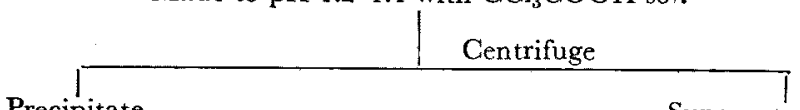

Precipitate

1

Redissolved in neutral or

weak alkaline reaction

Orcinol Diphenylamine $\stackrel{\downarrow}{\stackrel{\downarrow}{\mathrm{P}} \text {-reaction }}$ reaction reaction and determination for Supernatant fluid Neutralized with $\mathrm{KOH}$ sol. DNA

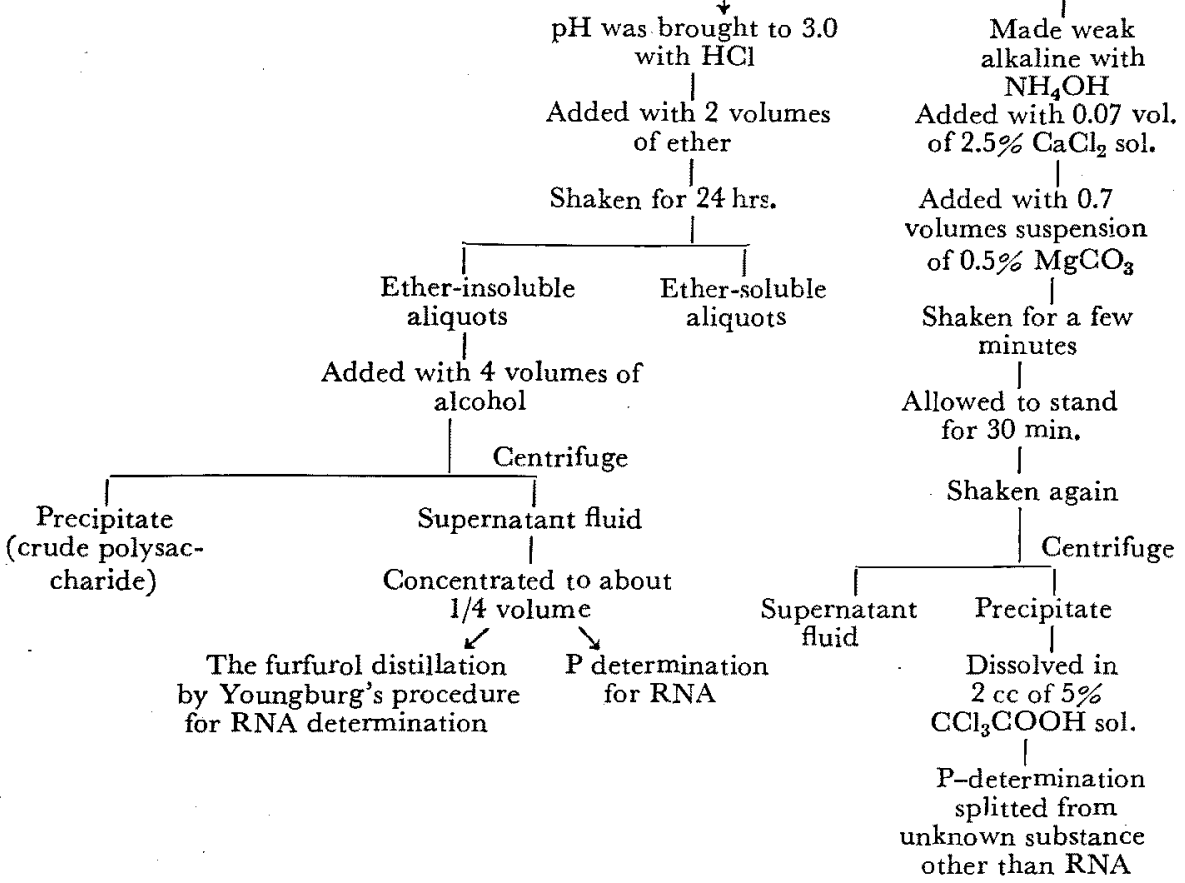

The Table shows the procedure to separate RNA and DNA from the dried bacteria and further to determine phosphor and furfurols isolated from the nucleic acids. The separation of two nucleic acids must be conducted as rapid as possible in a low temperature. 
The further procedures are shown in Table I and II. In order to remove as much "acid-soluble phosphorus" as possible the washed bacteria was extracted with 7 per cent trichloroacetic acid 2-3 times repeatedly, until phosphorus-reaction became negative in the extract. The extreacted solution was concentrated and tested upon phosphor reaction.

The fact that during the above operation, small amounts of organic phosphorus were detected in the extract with trichloroacetic acid, may be supposedly chiefly due to the polysaccharide contained in it, according to the knowledge obtained by the studies of bacterial body substances hitherto. As orcinol reaction was apparently positive, though Dische's diphenylamine reaction was negative, it may be undeniable, that small amounts of nucleic acids especially in the form of nucleotide, would be probably extracted too.

From the bacterial body substance thus obtained "phospholipide" was removed by boiling with alcohol-ether mixture and the residue was dried and powdered.

The dried bacteria was suspended in $50 \mathrm{cc}$ of $1 \mathrm{~N}$ potassium hydroxide solution per $\mathrm{g}$. and allowed to stand at $37^{\circ} \mathrm{C}$ until all bacterial substance dissolved completely. The solution was neutralized with hydrochloric acid and concentrated under reduced pressure to its half volume. The concentrated solution was added with alcohol at the rate of 40-50 per cent, brought to $\mathrm{pH} 1.2-1.4$ by trichloroacetic acid solution and centrifuged into two parts, viz., supernatant fluid containing RNA and precipitate containing DNA. The DNA containing precipitate was dissolved in neutral or weak alkaline condition, and confirmed upon the isolation from RNA by negative orcinol and positive diphenylamine reactions. Organic phosphor content was estimated with this solution for the determination of DNA. The colorimetric determination of DNA was not conducted, because commercial DNA to be required for it was too impure to be used as the standard.

The supernatant was neutralized by adding $\mathrm{KOH}$ solution, then concentrated to the half of its original volume. According to Delory, ${ }^{10}$ inorganic phosphor in this solution was determined, which was supposedly liberated from unknown substances other than nucleic acids after alkali treatment, while the total phosphor content was estimated in the other part of the solution.

For the purpose of determination of ribose according to Youngburg, ${ }^{11}$ i.e., by distillation of furfurol splitted from ribose it was necessary to remove contaminating polysaccharides previously, from the remaining supernatant. For this purpose the solution was brought to $\mathrm{pH} 3.0$ with hydrochloric acid and after adding with ether twice as much as the solution, the mixture was shaken for 24 hours and separated into two layers; ether- 
soluble and ether-insoluble. After adding with 95 per cent alcohol 4 times as much as ether-insoluble aliquots, the solution is centrifuged to remove the precipitated polysaccharide fraction. The supernatnat was concentrated to about $1 / 4$ volume and used for the estimation of phorphor and ribose by distillation of furfurol according to Youngburg. The precipitated polysaccharide fraction was proved to be weakly positive on phorphor reaction and evidently positive on Molisch's reaction. The fact, that the polysaccharide fraction was positive on phorphor reaction suggested, that more or less RNA would exist in it and this will reveal probably the difference of phosphor amounts existing between final fraction of RNA and its crude fraction just isolated from DNA. In any way phosphor and furfurol estimation was able to be conducted with RNA fraction thus obtained.

According to Schmidt, if the figures indicating the phosphor amounts are multiplied by conversion factors 10.6 and 10.1 respectively, it is able to obtaine the figures, indicating amounts of RNA and DNA. In case of RNA it is necessary to reduce the amount of phorphor estimated by the method of Delory from the total amount of phosphor contained in final RNA solution.

For the furfurol distillation after Youngburg's procedure, 85 per cent phosphoric acid solution was used instead of hydrochloric acid. Youngburg described that d-xylose yield 64.1 per cent furfurol and RNA 10.4 per cent by this method.

The author ascertained previously phosphor and nitrogen content of commercial RNA by the method of Fiske-Subbarow ${ }^{12)}$ and microkjeldahl, which gave a satisfactory result. The furfurol estimation was also conducted with the same preparation, furfurol being used as standard and with regard to RNA roughly similar values were obtained with those of Youngburg.

Anilin-acetate solution was used for the colorimetric determination of furfurol, after the mixture was allowed to standard for 40 minutes in a semidark or dark place.

With the procedures described above, the author estimated quantitatively RNA and DNA contained in the bodies of Salmonella abortivo-equina which were cultivated for $24,12,6,2$ hours and 30 minutes respectively.

As shown in Table III, the contents of RNA of shortly incubated bacteria was about twice as much as that of long incubated, while content of DNA in the latter was 1.5 times as much as the former. The rate of RNA to DNA, therefore, became the smaller, as the longer was the incubation period. 
TABEL III

\begin{tabular}{|c|c|c|c|c|c|c|}
\hline \multirow{2}{*}{$\begin{array}{l}\text { Incubation } \\
\text { periode } \\
\text { (hrs) }\end{array}$} & \multirow{2}{*}{$\begin{array}{c}\text { Dried } \\
\text { bacteria } \\
\text { (g) }\end{array}$} & \multirow{2}{*}{$\begin{array}{l}\text { P-amounts } \\
\text { by Delory } \\
\text { (mg.) }\end{array}$} & \multicolumn{2}{|c|}{ RNA (\%) } & \multirow{2}{*}{$\frac{\text { DNA (\%) }}{\begin{array}{l}\text { from P.- } \\
\text { amounts }\end{array}}$} & \multirow[b]{2}{*}{$\frac{\text { RNA }}{\text { DNA }}$} \\
\hline & & & $\begin{array}{l}\text { from } P_{-} \\
\text {amounts }\end{array}$ & $\begin{array}{l}\text { from colour } \\
\text { test of the } \\
\text { sugar }\end{array}$ & & \\
\hline 24 & 0.60 & trace & 6.2 & 6.0 & 3.9 & 1.5 \\
\hline 12 & 1.05 & $"$ & 6.8 & 7.8 & 3.3 & 2.2 \\
\hline 6 & 1.17 & $"$ & 6.6 & 7.3 & 3.2 & 2.1 \\
\hline 2 & 1.01 & 0.3 & 13.7 & 15.0 & 2.1 & 6.8 \\
\hline $30 \mathrm{~min}$. & 0.66 & 0.1 & 13.8 & 13.6 & 2.1 & 6.5 \\
\hline
\end{tabular}

\section{Conalusion}

The author estimated quantitatively by combined and somewhat modified method of Schmidt and Schneider, RNA and DNA of $S$. abortivoequina in various culture stages to establish the estimative method of nucleic acids of various microorganisms in various conditions and appearances.

The estimation of nucleic acids through carbohydrate component seems to be a very difficult problem owing to the existence of contaminating proteins or carbohydrates. However, the author has been able to remove polysaccharides as much as possible by the acidification of RNA containing solution in the presence of 4 volumes of alcohol for original solution. Moreover in the RNA containing solution it was possible by means of the distillation of furfurol to eliminate the influences owing to proteins and to exclude the consideration with regard to the difficulties of hydrolysis of purineand pyrimidine-nucleotide.

Leonardi and others described that the total amounts of nucleic acids of microorganisms occupy about 8-20 per cent of the dry weight of bacteria and the author's experiment brought out a result nearly similar with it. Besides he reported that the protein synthesis of the bacteria was vigorous and the amount of RNA increased at the same time in early stage of incubation, namely in "lag phase."

Actually the bacteria in this phase seemed to be in a "growing" stage from morphological point of views. On the contrary, the fact that DNA increased in later stage of incubation, suggested that it played an important role in the "multiplication" periode, viz. in so-called logrithmic stage, as Davidson ${ }^{13)}$ described, and this problem should be revealed by future investigations.

In conclusion I wish to express my sincere thanks to Professor M. Kuroya for his helpful guidances and his kind advices. 


\section{References}

1) Ris, H. and Mirsky, A. E., J. Gen. Physiol., 1949, 33, $125-146$.

2) Schneider, W. C., J. Biol. chem., 1945, 161, 293-303.

3) Schmidt, G. and Thannhauser, S. J., J. Biol. Chem., 1945, 161, 83-89.

4) Levene, P. A. and Bass, L. W., "Nucleic acids," Chemical Catalogue Co., New York, 1931.

5) Chargaff, E. and Vischer, E. Annual Review of Biochem., 1949, 17, 201-219.

6) Schmidt, G., Annual Review of Biochem., 1950, 19, 149-178.

7) Leonardii, M. G., Compt. rend. Acad. Sci., 1949, 229, 393-395.

8) Stephenson, M. "Bacterial metabolism" Longmans, London, 1950.

9) Levy, H. B., Arch. Biochem., 1949, 24, 206-215; Chem. Abstr., 1950, 44, 2597.

10) Delory, G. E., Biochem. J., 1938, 32, 1161-1163.

11) Youngburg, G. E., J. Biol. Chem., 1927, 73, 599-606.

12) Fiske, C. H. and Subbarow, Y., J. Biol. Chem., 1925, 66, 375-400.

13) Davidson, J.N., Annual Review of Biochem., 1949, 18, 155-182. 